\title{
Community-based water management: the oasis of Figuig, morocco recent extensions and transformations
}

\author{
Hasnaa El Jamali \\ Graduate Institute of International and Development Studies, Switzerland
}

Email address:

hasnaa.eljamali@graduateinstitute.ch

To cite this article:

Hasnaa El Jamali. Community-Based Water Management: The Oasis of Figuig, Morocco Recent Extensions and Transformations. International Journal of Environmental Monitoring and Analysis. Vol. 1, No. 5, 2013, pp. 213-229. doi: 10.11648/j.ijema.20130105.17

\begin{abstract}
Water is a prerequisite to mankind's life on earth; water management and governance constitute a primacy for policy makers. Discourses and theories of the Integrated Water Resources Management approach (IWRM) and CommonPool Resources (CPR) have been embraced in water management models. However, these discourses reveal shortcomings as they foster equilibrium models for water management. Past policies of water management have failed to offer effective water management. New vision for water management upholds an Integrated Management Approach embracing economic, environmental, societal, and participatory aspects. Groundwater has been a vital element in arid and semi-arid areas. Today, more and more overexploitation of groundwater resource is witnessed in North Africa and the Middle East (MENA), where increased population, climate hazards, and increased land users render the depletion of the resource a serious issue. Today the allocation of groundwater is torn between collective, i.e. community management, and private initiatives through the adoption of private wells. Suchsituations results in increased overexploitation of the resource and a race over pumping technology. The research is based on fieldwork conducted in 2011, in the Oasis of Figuig, Southeast of Morocco. Diverse methodological techniques were used including: direct observations, semi-structure interviews with 30 farmers, focus group with the participation of 13 farmers, and an oral history. The Oasis of Figuig, an intrinsic case for water management, is shaped by two water management models: community management inside the oasis and private initiatives established outside opting for new technologies. One of the research objectives is to examine community management and to illustrate the conditions under which people collectively manage the commons and the reasons behind peoples' free-riding. The study reveals that both community and private models of water management are relevant, complementary, and possibly reinforce each other. The case for "the death of the oasis" is not vindicated by current facts. The present research concludes to the enduring validity and viability of oases as they undergo renewal. Securing their long evolution, however, requires efficient and effective water management. These should focus on correcting the inequalities within community management and effectively monitoring free-riding.
\end{abstract}

Keywords: Community, Water Management, Oasis, Common-Pool Resources, IWRM, Free-Riding, Morocco

\section{Introduction}

Water constitutes an essential element and a condition to man's survival on earth. Policies and institutions have been put in place to ensure effective management. Central authorities, Water User Associations (WUAs), and the market have tried to find remedies for water management issues. Such management has been characterized by a topdown approach and has failed to deliver in terms of efficient management.However, it has recently moved toward the inclusion of community-based institutions and stakeholders, derived from the participatory discourses in the $70 \mathrm{~s}$ and in the $80 \mathrm{~s}$. The discourses against the effectiveness of state management were based on the failure of both the state and the market to provide efficient management due to changing local conditions and the difficulties in project replication. The state's control has seemed to fall short at providing adequate management of water, thus the shift to decentralization phase by encouraging community participation [1].

Community management has succeeded to fill the lacunae by minimizing economic support, initiating return on investment criteria, and encouraging farmers' participation [2]. Local community management has been the eventual alternative to both state and private control. Community discourse appears more and more as the answer for the sustainable use and preservation of natural 
resources [3].Managing water is even more critical in arid zones;arid and semi-arid areas have witnessed new changes and evolution in terms of agricultural activities. The oasis of Figuig, the case study of this research, is no exception. Figuig, one of the oldest oases in Morocco, is characterized by a traditional system of water management; the oasis has recently witnessed many changes regarding the management of its water supply and the technology used in its irrigation. As a response to demographic increase, expanding the cultivated land area has been a priority. New private investments have been established outside the oasis draining groundwater resources.

The case of the Oasis of Figuig represents a unique system of water management based on traditional canal irrigation and characterized by strong community management. Questions addressed with present research include: the conditions enabling people to get together in the collective management of common-pool resources and how is the common-pool system organized and managed.The Oasis of Figuig has recently witnessed further transformation outside its boundaries. The research additionally examines such initiatives and their effectson the oasis preservation and sustainability. Very little work has been conducted outside the oasis boundaries. This research aims to fill the gap in the literature on initiatives outside the oasis.

\section{Methodological and Theoretical Framework}

The research is based on two months' fieldwork in February and March, 2011 in the Oasis of Figuig. The research relied on the use of varieties of methodological techniques including: direct observations, semi-structured interviews with 30 farmers, focus group with 13 farmers, and an oral history conducted with two well-versed men in water management to understand the relation between irrigation and social organization.

\subsection{Theorizing Common-Pool Resources}

Social sciences deal with the issue of collective action according to two conflicting schools. The first school of thought regards man as a "self-interested individual" (homo economicus), as promoted by Adam Smith, Thomas Hobbes, and Ostrom. The second school, headed by Aristotle and Durkheim, however, regards man first as a "social-being," and second as an individual (homo-sociologicus)[2].The two schools express clearly the economic view of an individual self-interest and achieving the well-being through collective and community action in a sociological perspective. However, the schools undermine historical, socio-political forces affecting collective actions. Moss (1997) showed that there are many restrictions to the above theories; for instance, a community should be seen as strongly related to the political composition of the state. Adding to the importance of local, social and cultural factors, the historical context of the community is essential to understanding the logic behind collective action [2]. Two main schools came with a different vision. The first school, based on the "institutional-economic" approach, examines the following question: Under what circumstances will people work together? The second school examines social normsshaping the collective management[2].

For the analysis of common pool resources, many seminal theoretical works have been conducted to explain collective management of the commons. Common-pool resources has been an important issue in Mancur Olson's (1965) work "The Logic of Collective Action," in which he explained that "unless the number of individuals is quite small, or unless there is coercion or some other special device to make individuals act in their common interest, rational, self-interested individuals will not act to achieve their common or group interests" [cited in E, Ostrom, 1990, p. 6] [4].In the "Tragedy of the Common," Hardinpromoted the same idea as Olson; his vision was based on a common "pasture" where each individual seeking his or her own benefit ends up with diminishing the resource. Hardin's model examined the depletion of commons where and when individuals have unrestricted access. The dilemma fostered by Hardin has been used within the Prisoner's Dilemma. ${ }^{1}$ The scenario is about two prisoners who participated together in a crime and who are then questioned independently about the crime. In response to collective action in common-pool, an individual choice can be either 1- To free-ride and benefit from the common with unlimited access "shirks; while other users follow;" 2- To cooperate (as all users); 3- To follow while others do not; 4To act lawlessly as a sucker[5].The reality of individual choice in cooperating or defecting is not simple. As it is presented in the Prisoner's Dilemma, it is, on the contrary, complex. The theory has limitations and the conclusions concerning cooperation cannot be easily accepted as complex dynamics emerge within individual strategies. The Prisoner's Dilemma should be clearly evaluated. First, the two players decide in complete lack of knowledge about the answer of the other player. Second, the players are given just one chance to decide without the opportunity to make up their choices. However, such conditions do not exist in reality; the state, within international relations and cooperation, discern, in advance, the position of the other state before determining to cooperate or not[6].The dilemma explains that the two players cannot agree, and any adjustment may come from "outside." This scenario includes the supposition that the two players have not intended to cooperate beforehand whereas, in reality, players convey, exchange, and build possible cooperation [5].Prisoner's Dilemma, Tragedy of the Common, and the Logic of Collective Action all bring to attention the idea that collective action is not plausible, and they emphasize

\footnotetext{
${ }^{1}$ Among the pillar argument theories used in common-pool resources is the Prisoner's Dilemma, by Albert Tucker. The example of the Prisoner's Dilemma is applied to common-pool resources and the choices of each individual either to co-operate or to free-ride.
} 
the weakness of common-pool resources and collective management. However, a new wave of discourse has suggested alternatives and new approaches to the issues of collective action of the common.

\subsection{Recent Approach to Common-Pool Resources}

Three seminal scholars examined the issue of commonpool resources and reacted to the above theories; Robert Wade (1987), Elson Ostrom (1990), and Jean-Marie Baland \& Jean-Philippe Platteau (1996), by adopting different methodological frameworks; all recognized the important role of organizations in shaping the management of commons. They focused on social, political, and environmental aspects that had been disregarded previously[7].

In common-pool resources, institutions or what is referred to as "external enforcer of agreements" help people attain collective results. In response to the emergence of free-riders, institutions or the state implement rules and regulations to control the management[5]. In addition, some forms of collective management have succeeded through times to manage the commons and to establish rules and punishments. The conditions stated by the three scholars combine four main principles: 1- resources features, 2- group characteristics, 3-institutions 4- external factors: namely the market, state, and technology [7].The framework has 24 variables (see Table 1) explaining the conditions in which an effective management of a common-pool can take place to achieve the collective interest. The framework is not a model, but it would help in understanding the collective management of the common.

Table 1: Conditions for Common Pool Resources [Wade, Ostrom, Baland \& Platteau][3]

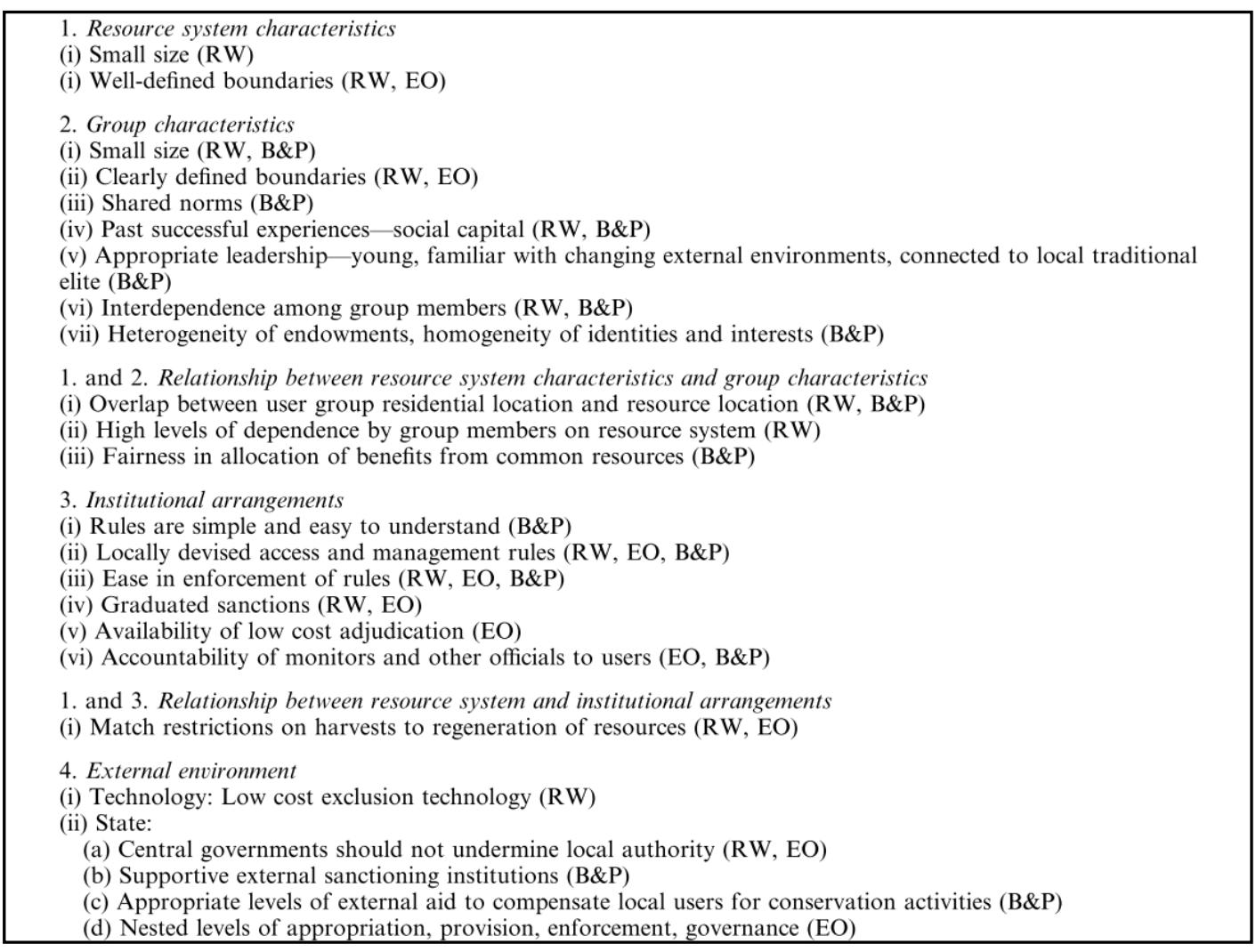

\section{Case Study: Oasis between Devolution and Evolution}

Oases can be defined as places of settlement, agriculture production, and stopovers for Saharan carnivals. Most works that have been conducted in the Middle East and North Africa oases have focused on two conflicting arguments: the first approach, during the 50s, examined the threat the oasis is undergoing as it deals not only with environmental hazard but also with human factors taming more and more groundwater resources. As a result, the literature lays stress on certain terms, namely the "death of the oasis," and "disappearance." However, the second wave, led by French studies, pictures the oasis in an evolutionary transition. This argument states that oasis space is in evolution and constant change due to the introduction of new technologies, new cropping patterns, and the increase in the area under cultivation[8].

The climate of Morocco differs from arid to semi-arid with variability in rainfalls. Morocco is shaped by diverse climate conditions. Precipitation ranges from $750 \mathrm{~mm} /$ year to less than $100 \mathrm{~mm} /$ year in the South mainly in the desert. Irrigation alone, as an important support for agriculture, consumes $85 \%$ of water resources whereas drinking water uses $12 \%$ and industry $3 \%$. The country's mobilized water 
resource is 20 billion cubic meters of water, which is divided between 4 billion cubic meters of groundwater and 16 billion cubic meters for surface water[9].The Oasis of Figuig, southeast of Morocco, is the closest one to Europe. The oasis is a Saharan land with springs irrigating palm trees, olives, vegetables, and fruits.Figuig is composed of seven different clusters known as qaşr, which is a defined territory with settlement and agricultural plots.Agriculture is the most important pillar for the oasis and its palm tree has many characteristics; it withstands harsh conditions, enables the practice of other cultures, and constitutes a socio-economic asset for farmers.

\subsection{Climate Constraints and Potential for Natural Resources}

\subsubsection{Topography}

The oasis is located on the High Eastern plain in the Saharan Atlas Mountains. Mountains, ranging from 1647 meters to 1000 meters, surround the oasis. The oasis is divided into two levels: a higher part, positioned on 930 meters high hill and a lower level of $860 \mathrm{~m}[8]$. The majority of the population inhabits the upper level, of mainly sixdistricts, whereas the seventh district is located at the lower level. The topographic map [Fig.1] presents the different mountains surrounding the oasis; these mountains not only provide the oasis with important water resources but they also protect the oasis on all sides.

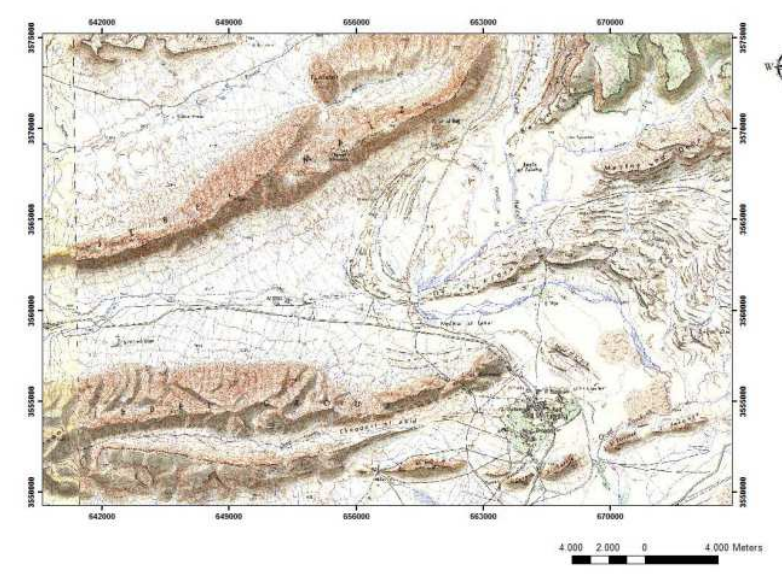

Figure 1: Topographic Map of the Region of Figuig[1/100.000] [10].

\subsubsection{Temperature and Rainfall}

The Saharan environment is characterized by high temperature in summer when the average temperature rises above 40degrees Celsius (July and August) to medium temperatures ranging from 1 degree to 5 degrees Celsius in winter. The highest temperature reaches 45 degrees and the lowest reaches 1 degree[11,16]. The high variability in the climate and temperature affects and shapes agriculturalproducts, irrigation and, most importantly, water availability. The following graph[Fig. 2]shows that the oasis experiences sharp rainfall variability from one year to the nextand high temperatures, which affect the oasis and its agricultural products.Rainfall variability, hot temperatures, and strong winds all affect the plot especially in summer when the land is in need of greater quantities of water, thus leading in a strong water shortage. The oasis is also affected by extensive years of drought making it difficult to satisfy the demand of water for irrigation, a fact that leads to extracting fossil water.

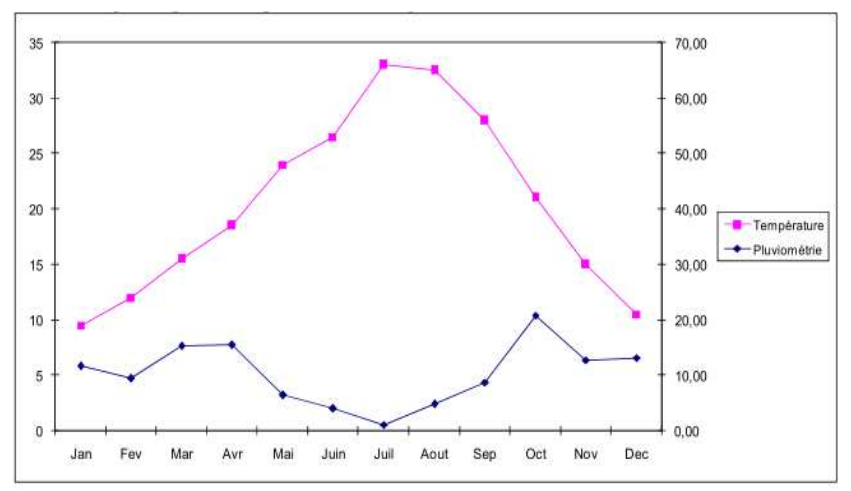

Figure 2: Ombrothermic Diagram in the Oasis of Figuig[10]

\subsubsection{Wind}

The speed of the wind varies between $60 \mathrm{~km} / \mathrm{h}$ and 1 $\mathrm{km} / \mathrm{h}$. Wind begins to be cold from the month of October, to become a hot wind, known as "chargui," a strong current filled with sand in the months of June and August. However, given the geological characteristics of the oasis, the mountains surrounding the oasis prevent the wind from having any negative effect on agriculture [11, 12].Spring winds, help in the pollination process of palm trees, mainly between February and April, a fact that was witnessed during the fieldwork.

\subsubsection{Population and Migration}

The oasis is a melting pot of different races and ethnic groups. The first arrivals were the Berbers "Zenetes" "Senhaja"who inhabited the lower part, the district of Zenega. After their arrival, many Arab groups established themselves in the oasis at different periods; "shurfa," people descended from the prophet, settled in the upper part, the district of "Lūdāghīr." Adding to these groups, Muslims from Andalusia, African groups "Haratine" and Jews settled in the oasis, the latter resided there until the middle of the $19^{\text {th }}$ Century[13].

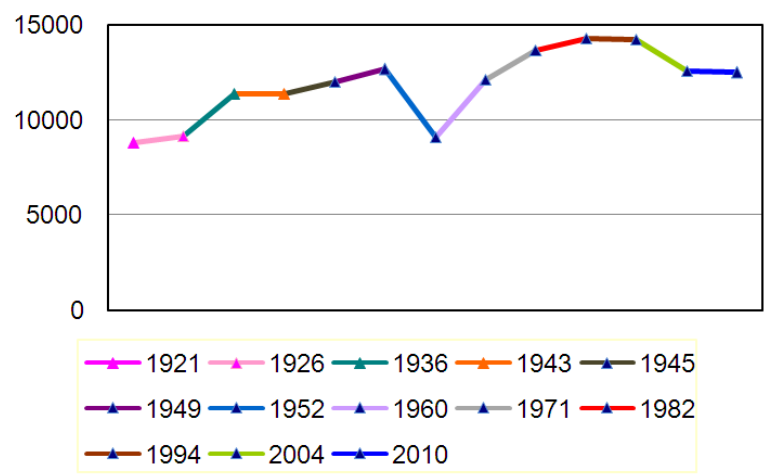

Figure 3: Population of the Oasis of Figuig[1921-2010][11,14]. 
According to the graphabove [Fig. 3], the oasis witnessed major shifts in short periods. The oasis went through two different migration types: a finite migration, where the whole family moved from the oasis. Such families happened to have no water rights or had few. The second kind of migration is sequential, where the migrant leaves one or more members of his family behind to watch over the land, water rights, and the family household. The remaining family benefits from the remittance sent by the migrant to buy more water and land rights[8].According to Bencherifa and Popp (1992), 70\% of the sequential migrants, who went abroad to either France or Algeria, worked in industry, mining, and business. For instance, in the Lüdāghìr cluster, $60 \%$ of males migrated from their households, in the 1980s [8].Today, the number of migrants settling abroad is 1,417 , while internal migrants in Morocco are 838 , a total of more than 2,200 , which is $32 \%$ of the total number of active people[11]. Migration has been an important concept in the oasis. It has shaped farmers' strategies, land organization, and the economy of the whole oasis. What are the reasons behind such migration? How does it shape the oasis space and farmers' revenue?

\subsection{Water Resources: Surface and Groundwater Potential}

\subsubsection{Surface Water}

The oasis has three main rivers: the river of Zousfana (East), River Kheng (West), and river Lakbir (North). Irregular, short-term, and violent flows of water cause damage in the oasis. Though Figuig does not have a hydrometric station, the river of Zouzfana, the mostimportant one is dry most of the time [15]. Additionally, the Oasis of Figuig has two main aquifers: a deep aquifer or "nappesprofondes" and water tables, or "nappesphréatiques."

\subsubsection{Groundwater Resources}

Given the absence of surface water and its scarcity, groundwater resources play a decisive role in the survival of the oasis. One of these crucial groundwater resources emanates from the mountains surrounding the oasis. It is the only resource provided in the oasis for agriculture, which is strongly dependent on irrigation, which, in turn, is dependent on underground resources. Figuig has around 30 springs, $90 \%$ of which are located in the upper hill with different water flow levels as shown in the piezometric cards (2004) (Figs. 4 and 5) presented below. The main source of water comes from the mountains that surround it. For instance, the mountain of Larmour, located north of the oasis, has $400 \mathrm{~mm}$ of rain per year and snowy seasons. Important quantities of groundwater flow from the mountains towards the oasis and emerge as springs. Water sources have high temperatures ranging from 27 degrees to 34 degrees, ${ }^{2}$ which explains the deep aquifer origin of the spring resources [16].

${ }^{2}$ In the past, parts of the spring were used by the community as public bath called «Hammam » (Oral history).
"Water table is located in the blue Lias limestone containing marly intercalations; namely around 30 spring sources are identified in the upper part of the oasis whose water used to be extracted by Foggara ${ }^{3}$ technique. The sources are fed by a system of significant splits of an injected clay pattern that comprise an underground dam." [Professor Al Otmani, Personal Communication, March $\left.14^{\text {th }}, 2011\right]^{4}$

\subsection{Aquifer Evolution and Variability: Water Spring Resources}

According to the aquifer evolution and variability, variation can be noticed regarding the water flow in the past 50 years. As shown in the graphabove [Fig.6], the water flow was more than halved from 1925 to 2004 . "The flow of the spring is strongly related to rainfall, one can notice a decrease in the level of the spring when the oasis has less rain. In 2002 and 2005, two sources dried because of extensive years of drought but in 2008, we witnessed an increase in water flow due to important rainy seasons; the sources were revived" [Asraifi, personal communication, February $\left.23^{\text {rd }}, 2011\right]$. The first official measurement of spring water flow was made in 1975.However, according to some Sarayfi, the report and the volumes in water flow are underestimated since the report ignored the introduction of the pumping station in 1962 [8][Sarayfi, focus group confirmation, personal communication, February $19^{\text {th }}$, 2011]. Today, the water flow in the oasis is around $22 \mathrm{~L} / \mathrm{s}$ in good rainy seasons, and it can reach $18 \mathrm{~L} / \mathrm{s}$ or less in a drought.

\subsection{Historical and Geopolitical Background}

In evaluatingwater management, it is crucial to examine the relation between the physical dimensions and the sociohistorical organization inside the oasis. The oasis played an important role as a caravansary of Saharan trade, and it constituted an important stopover for pilgrims going to Mecca. This situation developed commerce and trading sectorsand it enriched an artisanal sector. However, this important situation changed on the eve of French colonization of Algeria (1830); the latter created new routes for commercial exchange [17].This shift resulted in economic deterioration and political crisis in the oasis. What is more, the oasis was deprived of important pieces of land. During the 1963, "La Guerre des Sables," Algeria and Morocco were in conflict regarding lands located near the borders. This geopolitical conflict resulted in the drawing of new frontiers, depriving farmers of their ancestral lands located on the Algerian side of the new boundary. Based on 1975 statistics, Figuig farmers lost around 90,000palm trees to Algerian farmers [19].Consequently, many settlers opted for migration as a solution to their economic issues.

\footnotetext{
${ }^{3}$ The Foggara is an underground system used to collect water for irrigation. ${ }^{4}$ See also [15].
} 


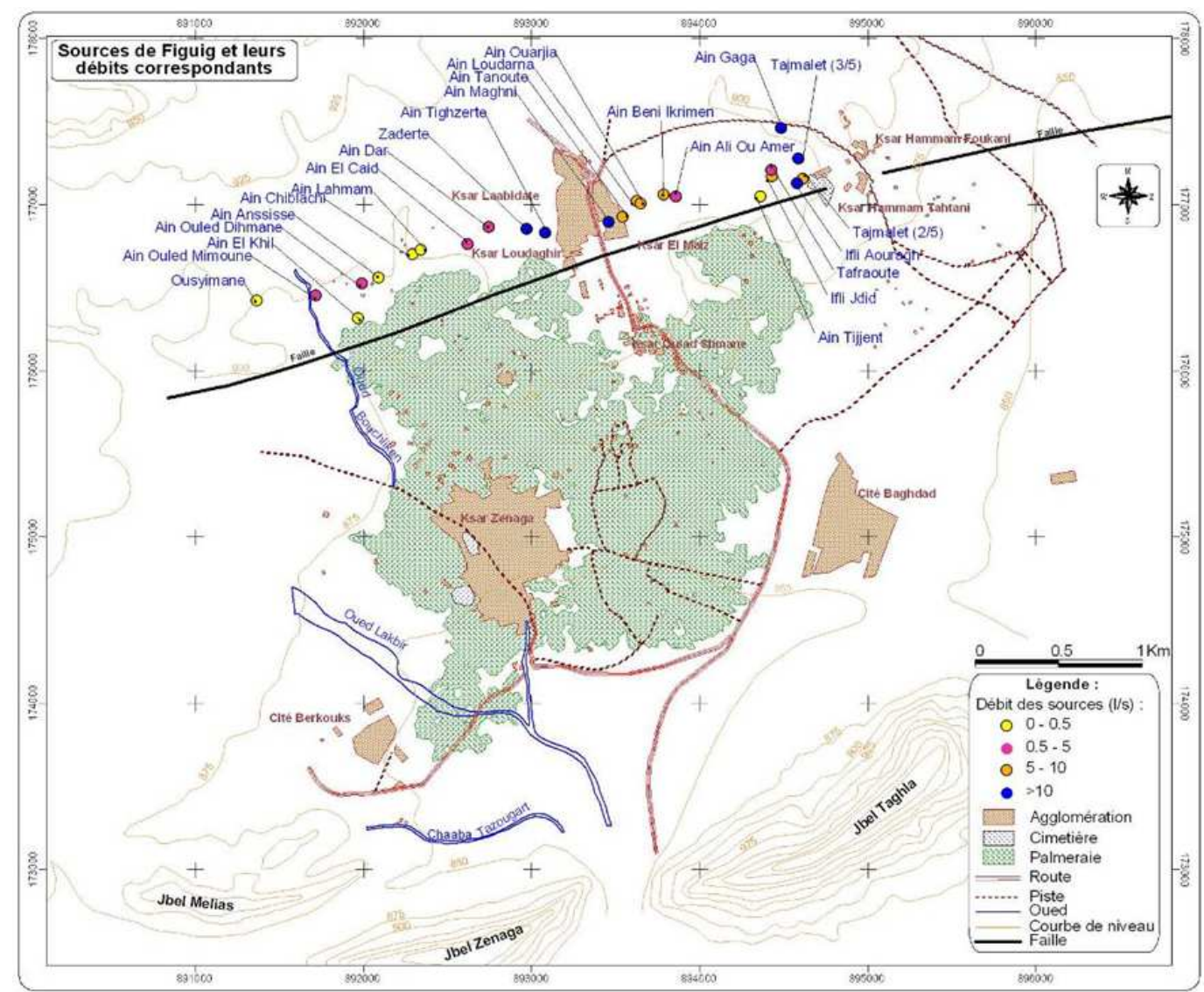

Figure 4: Springs of the Oasis of Figuig[15]

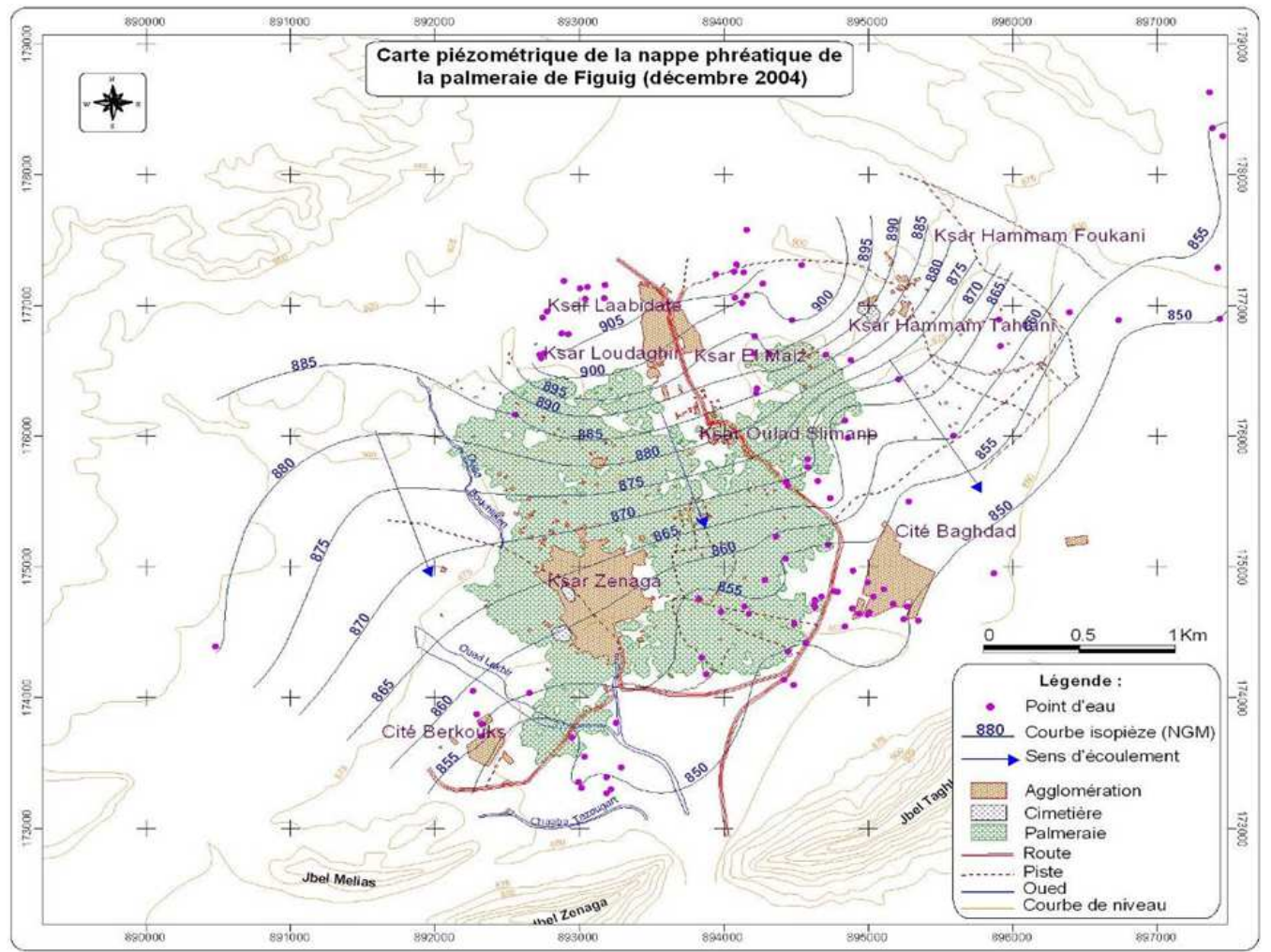

Figure 5: Piezometric Card of Water Tables in the Oasis [15] 


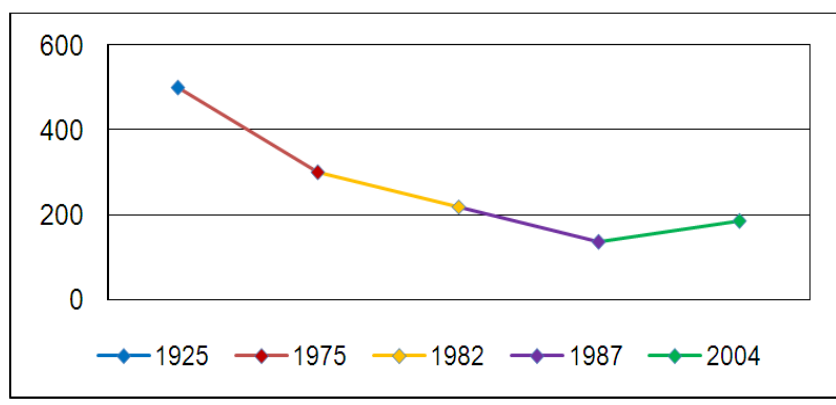

Figure 6: Water Flow $[L / s][18,19]$

In addition, following attacks in Marrakech in 1994, the border between Morocco and Algeriahas been closed ${ }^{5}$. As a result, the economic exchange between the two countries has been affected. Today, the oasis is suffering from its land deprivation, closed borders, and an isolated geographical location, where only one national road links the oasis with the rest of the country.

Thus, many factors such as the variability in rainfall, high temperature, limited surface resources, drought, a deteriorated trading system, and isolation all affect the good potential of groundwater resources in the Oasis of Figuig.Nonetheless, today, agriculture, which relies solely on groundwater resources, is the core sector of the oasis economic activity. What is more, all of the above physical and geopolitical conditions have affected the social system in place. The isolation helped in preserving the characteristics of the system of water management, and, at the same time, at enabling an examination of the manner in which people succeeded, under such conditions, in maintaining a form of water management system. This system of irrigation sustained the oasis, and it has managed to function for a long period. Therefore, we examined the conditions enabling such community management of the common and the social system in place. Throughout the analysis, the theoretical framework drawn from Ostrom, Wade, and Baland \& Platteau on the conditions behind collective management of the common wasadopted.

\section{Discussion: Water Management, a Community Approach}

\subsection{Resource System Characteristics: System of Irrigation and Agriculture Management}

Irrigation is viewed as the backbone of water management; it consumes 90 per cent of all water use, and it withdraws 70 per cent of availablewater [20]. For an effective irrigation, embracing modern technologies is fostered in order to promote efficient water supply, to meet the high demand, and, at the same time, to preserve a scare resource. The following notions play a vital role in shaping technology use: economic, institutional, and environmental

${ }^{5}$ Morocco blames Algeria for being behind the attacks. aspects all determine the technology of water management [21].Recently, the use of low-cost technology, mainly the use of pumps and wells to increase the productivity and the use of groundwater resources, has increased significantly. For the Oasis of Figuig, given the scarcity of surface water, groundwater and springs are mobilized to irrigate crops. In the past, the system of irrigation relied on Foggara or "Khettara" system, an Iranian technique, known differently as qanat, karez, and falaj, butin Figuig it is called "Ifli." The technique uses gravity to distribute water from the hill to the plots through canals.

Extensive years of drought, decreased water flow levels, together with difficult topography all affected the technique used for irrigation. Most spring sources are located at the upper level of the plane, while most farms are down the hill. Due to thedifficult topography thisparticular cluster is facing, there has been a need for a new technology; thus, the introduction of a pumping station in 1965. InLūdāghìr cluster, the community decided to replace the old khettara system in order to mobilize more groundwater resource.

\subsection{Irrigation System}

1. Pumping station: In 1965 , the community set two motor-pumps that worked withelectricity, which they converted to dieselfuel, starting in 1994. Today, the community has five motorpumps (see Fig.7) working alternately between 15 to17 horsepower andseven meters deep. The prices of the engines range from $\mathrm{Dh} 7500^{7}$ to $\mathrm{Dh}$ 16.000; they were brought on the revenues from the money generated from water rights rentals.

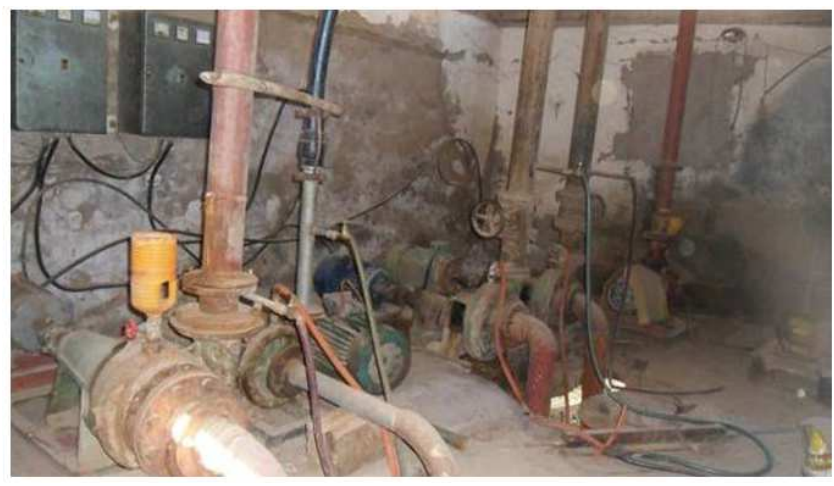

Figure 7: Pumping Station

\section{2- Collective basin known by la Croix. ${ }^{8}$ The}

basin (Fig. 8) was constructed in 1961 by the collective community.It is a basin of 40 meters $* 40$ meters and 3 meters deep used to store water before distributing it through canals.

${ }^{6}$ Berber tribes and tribes from zenate introduced the technique of Khettara or Foggara, which is known by the name of "ifli" the plural of "iflan." ${ }^{7} \mathrm{Dh} 1=$ Euros 0.08 .

${ }^{8}$ The reason behind the name "croix" is the presence of a cross by the middle of the basin to protect walls from any strong winds that might harm the basin. 


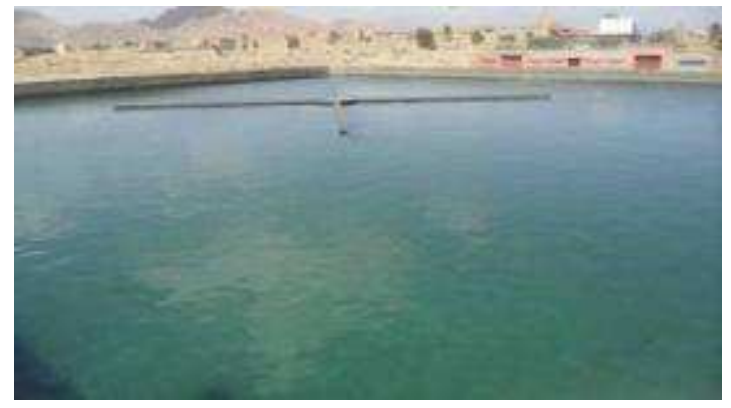

Figure 8: La Croix basin

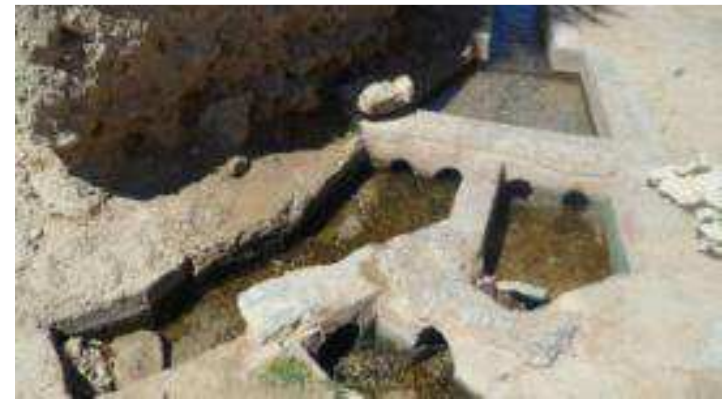

Figures 9: Iqūdās leading water to the basin

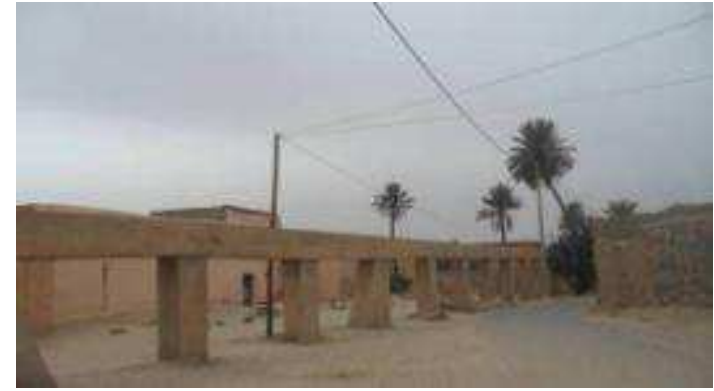

Figures 10: "Saguia" leading water to the basin

3- Main canals known as Iqūdās are complex and have three different functions:

- Canals that bring water from the pumping station to the shared basin, known as "saguia." Two hundredmeters long uncovered canals to reach a collective basin (Figs.9-10).

- Canals that bring water to the plot; they are characterized by complex structures and shapes according to the different plot within the cluster (Figs. 11-12).

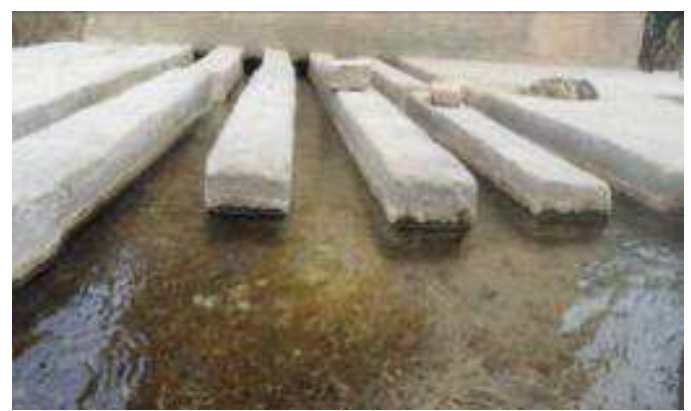

Figures 11: Iqūdās Canals

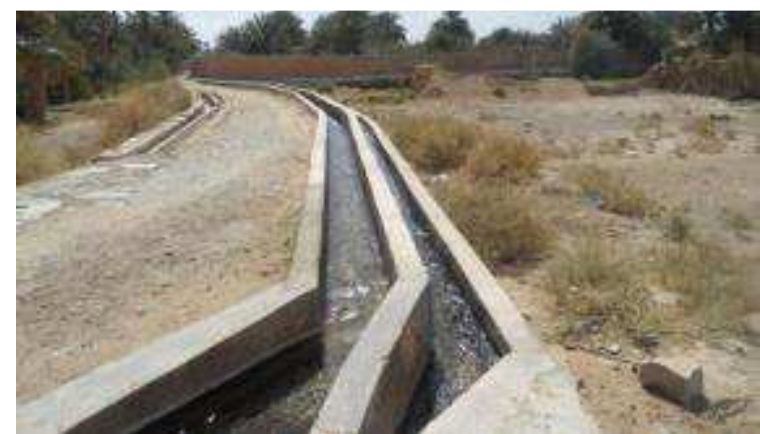

Figures 12: Uncovered canals

Canals that are used for irrigation inside the farmer's plot either buried or uncovered (Figs. 13-14).

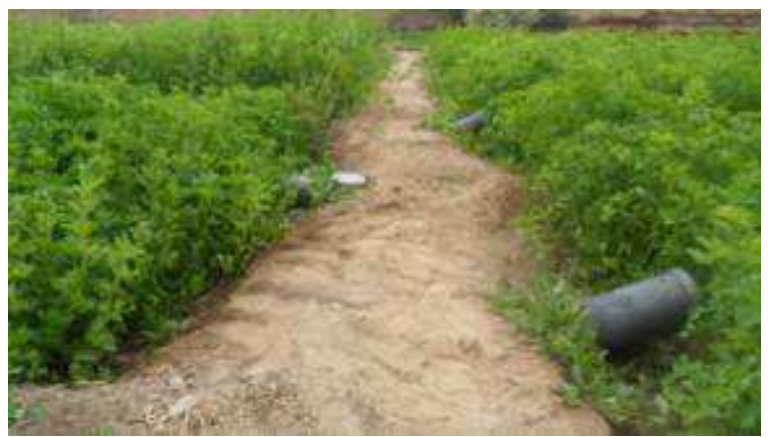

Figures 13: Buried Canals inside the Parcel

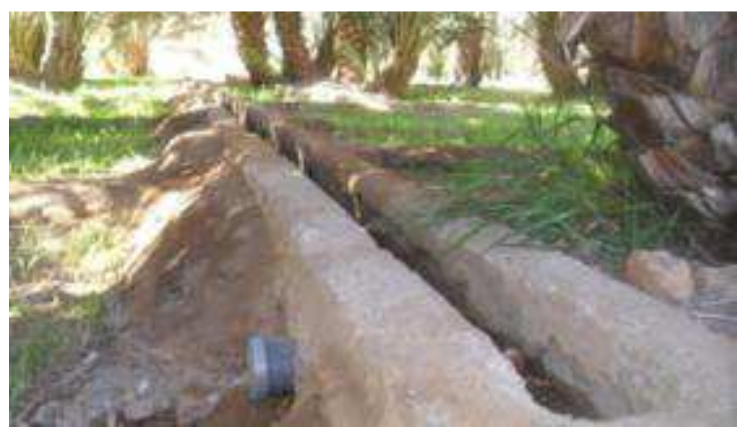

Figures 14: Uncovered Canals inside the Parcel

4- A well-respected man called "Sarayfĭ", designated by the community, manages water issues and water rights.

5- A basin or "sahrij" in the plot helps control the time and the quantity of irrigation, 8 meters $* 11$ meters and with 2 meters deep, the basins have different sizes according to farmers' land. The role of small storage basin is to avoid wasting water and waiting for one's turn for water. Based on water management discourses, the case study revealed that water management is mobilized and boundaries are defined mainly by the presence of two physical characteristics, i.e., the stationary and the harnessing of the natural resources and the presence of defined group of users with definite water rights.

In the traditional system of irrigation, water is a private good; the farmer can inherit, sell, and buy water rights, which are transferred from father to son justified by an official document or an entitlement called Al kade. Each farmer gets a volume equivalent to 45 minutes of water 
flow; for instance, 24 hours is equivalent to 32 kharūbāhs; In other words, $24 \mathrm{~h} * 60 \mathrm{~min} / 32$ kharūbāhs $=45 \mathrm{~min}$. In the Tighzert spring in Lüdāghìr, 45 min of water flow is equivalent to 11.88 cubic meters. A day's flow is equivalent to 32 kharūbāhs worth of a day and night turns. The system of water management is characterized by a water market. Farmers, who have less private water rights, can rent some from the community or $J m \bar{a}$ ' $a h$. The price for one rented kharūbāh is Dh 60 during agricultural seasons. ${ }^{9}$ The water cycle extends over 15 days, but the community adds a day to the cycle called "tanatawte," whose money is used for collective projects like building the basin and the pumping station, in addition to securing regular maintenance of the infrastructure. Today, the additional day is devoted to the new users wanting to buy or rent water rights. The system of irrigation adopts both modern technology of diesel motor-pumps and traditional techniques, which can be organized by the presence of traditional infrastructure for irrigation.

\subsection{Group Characteristics: Community Management Social Organization}

\subsubsection{Small Size and Defined Boundaries}

Since early on history, Figuig has benefited from an autonomous system of governance. The central authority appoints local people from the oasis to govern on the basis of strong community management system headed by elders. The latter are knowledgeable and respected figures, thus forming $J m \bar{a}$ 'ah, a local community system. As a result, community or Jma'ah has been the main actor in the management of water as it has benefited from an autonomous level of governance. Community management has a small size with defined boundaries; the district of $L \bar{u} d \bar{a} g h \bar{i} r$ has a surface area of 93 hectares and 144 users, its boundaries are defined, as access is restricted to people having both water and land rights called "At-Lasal" or people owning water rights. The Oasis of Figuig is characterized by a system of social hierarchy that is based not on the person's wealth but on family lineage and roots.

\subsubsection{Homogeneity and Shared History}

The fieldwork focused on Lüdāghìr cluster inside the oasis, which has strong homogeneity among its members, as compared with other clusters. This can be traced back to the shared family roots the community cluster enjoys. Several of the families share common family trees and the same ancestors. Consequently, the cluster demonstrates strong social harmony, shared identity, and strong "social capital" to use sociologist Bourdieu's concept,a fact that is not found in other clusters in the oasis. ${ }^{10}$ Adding to their strong social position, the possession of financial wealth has

\footnotetext{
${ }^{9}$ The latter is divided between a winter season with seven months and a summer season with shorter period of five months.

${ }^{10}$ Other clusters however do not have such harmony since members of the group came from different places in Morocco. Most of them do not have shared roots as the case in Lüdāghìr cluster.
}

helped the sherifian ${ }^{11}$ families of the community. Sherifian people have been involved in decision-making regarding the cluster[13]. However, the rest of the social group has been excluded from the decision-making process.

Not only does the community have shared norms, but it also has a shared history of water sustainment. The community witnessed fierce and intensive years of war, with the Zenaga, other cluster, over water springs. ${ }^{12}$ Fighting for many years over one goal has strengthened the "social capital" of the community, which is cohesive in the collective tasks performed by the $J m \bar{a}$ ' $a h$, namely, building the foggara, and sharing the basin and canals infrastructure. Importantly, the community organizes a day devoted to collective work called "twiza," where farmers help each other in collecting the harvest and performing collective tasks. Given the importance of and the reliance on agriculture and water within the community, the spring and the plots of land are closely identified with farmers' settlements. The importance of the land as a means to sustain identity roots explains the proximity of land from the settlement for easy watch and supervision.

\subsubsection{Legal and Institutional Arrangements}

Such a traditional system is bound by specific rules and regulations. The community relies on customary rules or "Urf," which is an oral, unwritten code of rules known to all members of the community and used to manage irrigation problems, to grant sanctions, and to settle dispute. For example, the " $U r f$ " rules allow any farmer to use water from the common canals under two circumstances: if the farmer is doing construction on his plot of land or if he wants to irrigate new palm trees as they need water every three days[Nacer Eddine, personal communication, February $\left.10^{\text {th }}, 2011\right]$. The system of management is accountable, for it has, for all users, official documents about the number of water rights and the irrigation time assigned to every farmer. Concerning the legal framework, community water management has been autonomous only with regard to thelocal irrigation system. Tracing to the colonial period, water itself was made public property. Hence, the state could influence agricultural policies reforms by making water into a public domain. Examination of the legal framework of water rights reveals two contradictory laws: The customary law, or the "Urf," used mostly by Berbers in rural areas, considers water a private ownership. Nevertheless, Islamic law, or "Charia," regards water as a public good[22]. However, Islamic law considers groundwater a private good. As land ownership gives the landowner the right to use underground water.

Assessing the legal framework of water in the country verified that both legal and customary water rights exist side by side. The customary law indicated has been practiced and tolerated by Muslims for political reasons with the purpose of ensuring stability in the country

\footnotetext{
${ }^{11}$ Sherifian families descended from the prophet.

${ }^{12}$ The Zenaga cluster is the largest cluster located south of Lüdāghìr cluster.
} 
between Berber and Arabs. Today, in some rural areas in Morocco, customary rule is being followed more than modern legal law;Figuig is no exception. In a global perspective, community management is considered an autonomous system having distinct rules and customary laws defining different stakeholders' water rights. Community management, according to the state, abides less by its rules and laws, which signifies less control. At the same time, rules that associate owning land with the right of using its fossil water lead to overexploitation and a pumping race. Even though the country acknowledged the right to customary water rights, different strategies can take place at the local level, thus affecting water management and the adopted legal framework. Along the same line of argument, individuals can scrabble between different rules to satisfy their own needs and interests.

\subsubsection{Irrigation Technique}

Irrigation in the oasis is done by a flooding technique or "tasrount" known also as "rabta" to deliver water in the plots. A plot is divided into small sections known as "gammoun," which is the smallest part in agricultural property in the oasis [19]. Most gammouns or plot measured acreage to 10 meters * 2 meters[El Hilali, personal communication, March $\left.4^{\text {th }}, 2011\right]$. The shapes of such plots can be either vertical or horizontal according to the nature of the crop and the size of the land area. The adoption of the pumping station in 1965 shows the flexibility of the system and the readiness of the community to adopt new technology to supply enough water and to face the oasis aridity. Recently, farmers have used plastic pipes buried alongside route lines to preserve water inside their plots. However, adopting new technology is strongly correlated with financial factors. Is the community able to finance the pumping station in a longterm vision? What would be the drawbacks of such technology?

Contrary to the theories of Prisoner's Dilemma, Tragedy of the Commons, and Collective Action, the results of the study shows that community management is proven possible. People have gathered to manage collectively an irrigation system sharing to distribute water rights and to have irrigation infrastructure assembled. Defined and small-sized groups, strong "social capital," and successful experience of sharing common good characterize the resource system. All have resulted in effective and strong community systems sustaining the management of water for irrigation. Can one consider that community is thus homogenous and successful in managing water within a collective entity? What are the factors shaping such a management? Even though the traditional system of irrigation appears to be efficient, it hides important disparities. This system of equality undermines and hides inequalities and challenges affecting its sustainability.

\section{Analysis: Evaluating Community- Based Natural Resources}

\subsection{Homogeneity versus Heterogeneity: Socio-Economic Inequalities}

As discussed earlier, there is a need to distinguish and recognize that communities are heterogeneous groups in which individuals seek to establish their own interests and benefits. The water management system lies at the core of the social network, as it strongly contributes to shaping group identifications, social hierarchy and cultural values. For instance, even though water sharing is presented as a fair system, it is not immune to power relationships and individual strategies[23]. The community of Lū $\bar{a} g h \bar{u} r$ faces these challenges.

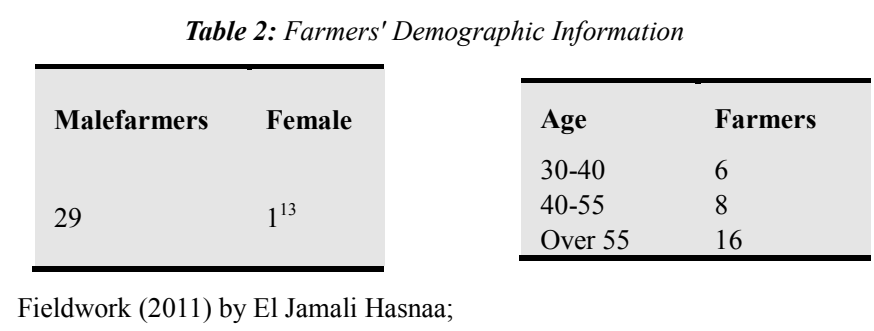

$\mathrm{N}=30$

Based on the above data [Table 2], and given a patriarchal society, there is a strong power appropriation by male farmers, over 55 years old. Even though the Integrated Water Resources Management approach (IWRM) fosters women participation, the oasis has remained male dominated, where women play a minor role. Even if the community has small-size group with defined boundaries, the system has social hierarchies and different social and economic arrangements. Official Bulletin of 1975showed that all water rights are held by three families from Lüdāghìr (Hadj Boufelja, El Hilali Larbi, and Mohamed Ben Aissa Ben Yahia) [18]. The fieldwork revealed that, among the 1440 kharūbāhs owned by the member community, two single sherifian families own 84 kharūbāhs of water rights and 60 kharūbāhs, respectively. In other words, the two families own $10 \%$ of all water rights.

\subsection{Inequities in Land and Water Sharing}

Even though there seems to be equity in benefiting from water every 15 days in winter and every 7 days in summer through "le tour d'eau," the quantity differs according to the amount of water rights owned. The Jma' ah in the oasismanaged to keep rented water rights at a lower price, yet not all farmers benefit from it. What is more, water rights vary according to the fluctuating water flow of water springs, as it is dependent on environmental changes. The

\footnotetext{
${ }^{13}$ The female has a minor role since the labor takes charge her land. During an interview, she stated that she will assign her son to take after the work.
} 
community spirit thus seemed to be reduced. In earlier times, the Sarayfitook care of water management and distribution but now farmers do it themselves. Every farmer who owns water rights removes the rocks from the irrigation canal to enable water to get to his own plot [24].The $J m \bar{a}$ ' $a$ h, as a legal body, has today a shadow rule and was dismissed by an association. "Decision-making over water management in the Oasis of Figuig is torn between a respected and well-versed $J m \bar{a}$ ' $a h$ and a new association, thus, leading to two conflicting groups whereby one is insisting on the credibility of the $J m \bar{a}$ ' $a h$ and the other one on promoting the association" [Fadili, Personal communication, February $\left.21^{\text {st }}, 2011\right]$. As a result, such situation leads to a duplication of decision-making and affect the management. Going back to the IWRM, such approach enhances the participation of community; however, given the heterogeneity inside the group, the level of participation is affected. Influential farmers owning most water rights would shape the decision in their interest.

There has been an inequity in both water and land rights allocation between members of the community. In earlier times, the community participated collectively to drain water springs and build a collective khettara system. Participating families, either for their physical force or fortheir financial means to the irrigation infrastructure, were allocated water rights, thus creating disparities inside the community. For instance, one family benefited from one day of water flow whereas others had only a few hours. However, this model underwent change and a new arrangement took place, which affected socio-economic conditions facing the oasis, amongst which is migration. Many disparities exist between owned water rights and rented ones. Farmers owning fewer water rights tend additionally to rent to meet their needs. However, the monopoly of both rented and owned water rights is in the hand of few privileged farmers. The size of their plots andthe ownership of water rights also affect the profitability of the land, as does the migration phenomenon.

Sharp disparities are omnipresent in both land and water sharing as presented in [Figs. 15 and 16]. The larger number of farmers own small land plots ranging from ha 0.001 to 0.99 in size. The latter results in the "morcèlement" or the "parcelling" out of the land and the intensification of different agriculture products inside a small plot. In the same line of argument, smaller water shares (0.001- 0.49 number of kharūbāhs) are owned by a large number of farmers, whereas larger kharūbāhs are monopolized by few farmers; the same holds true for rented water rights. In addition, the strong competition over scarce water has affected the price of both the ownership and the rented water rights making it hard for poor farmers to increase their water rights. The price of the ownership of kharūba $\bar{h}$; for instance, has increased from $\mathrm{Dh}^{14} 10$ to $\mathrm{Dh} 3,000$ from 1933 to 1955 ; it doubled in 1970.After the adoption of the pumping station, it rose to $\mathrm{Dh} 30,000$, to reach $\mathrm{Dh} 42,000$

\footnotetext{
${ }^{14} \mathrm{Dh} 1=$ Euros 0.08
}

in 1995. The rental kharūbā $h^{15}$ has increased from Dh 30 in to Dh 200, from 1964 to 1952. In1993, a ten-fold increase reaching $\mathrm{Dh}$ 300. Based on farmers' testimony, the price of the rented water rights is still affordable vis-à-vis the ownership of water rights, which is much more expensive. Given this hastily changing economic factor and the increasing prices of water rights, water management discourses failed to picture such change and based their approach on a constant and balanced model.

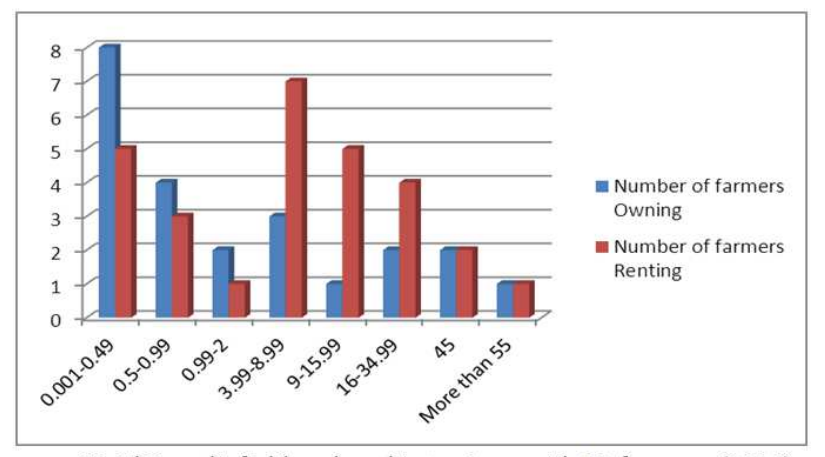

H, El Jamali, fieldwork and interviews with 23 farmers, (2011)

Figure 15: Water Rights Distribution [water rights/ kharūbāhs] ${ }^{16}$

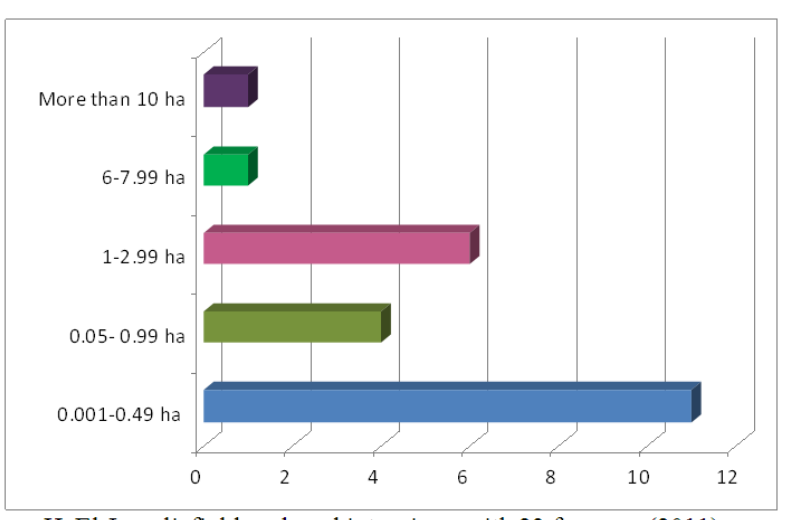

H, El Jamali, fieldwork and interviews with 23 farmers, (2011)

Figure 16: Land Ownership Inequality [hectares]

\subsection{Drawbacks of the Traditional Irrigation Technique: New Practices and Initiatives}

The system of water allocation and distribution in place is inefficient. Large amounts of water are lost within canals before reaching the land especially with the increased temperature in summer. Additionally, the flooding technique used is not an effective method, for it causes a lot of waste. In relation with CPR theories, farmers face issue of appropriation especially when the quantity of water is not enough for all stakeholders[25]. The quantity of water the farmer receives differs from one farmer to another according to his water rights and the location of the land in relation to the collective basin. Plots positioned far from the shared basin receive a smaller quantity of water. The latter

\footnotetext{
${ }^{15}$ Renting is done every six months before the start of the agriculture calendar.

16 One kharūbāh amounts to 45 minutes of water flow.H, El Jamali, fieldwork and interviews with 23 farmers, 2011.
} 
can be reduced in quantity due to evaporation through the canal distribution and the time it takes to arrive to the land. In addition, drinkable water is used for irrigation given its cheap price compared to the rented one. ${ }^{17}$ Drinking water in the case of the Oasis of Figuig is controlled by the local municipality, unlike other cities in Morocco where the private sector is in control. In 1997, the country allocated the management and the allocation of water to the private sector, however, in some area the municipality is still in control of the water sector. Though potable water prices are cheap (around Dh 30 per three months) water quality is sharply criticized.

Given the recent changes with the variability in water flow, the measurement of water rights did not change, and, thus there is not enough water for irrigation. Farmers used to irrigate directly but today they need to store water in the small basin for days to be able to have a sufficient quantity of water [19]. Given this context, new farmers' strategies took place; a water market has recently emerged between farmers selling water to each other with a high price that can reach Dh 50 per hour for people having a basin inside their plots. A fact that can pose problems and weakens the community management system, but at the same time, the community needs to think of possible alternatives to increase the quantity of water needed for farmers to avoid any possible use of individual wells within the collective system. From mapping the plots, one can state that a typical plot has four types of agriculture culture: cereals, fodder crops, palm trees, and fruits (arboriculture). The system requires the inclusion of more than one culture in the same plot given its small size. The farmers use this intensive technique since palm trees allow the presence of other crops. However, given the scarce resource, a farmer establishes his priorities according to water availability. In case there is a lack of water resources, palm trees will prevail over other cultures. Livestock is an activity devoted to self-consumption; only small numbers of sheep were noticed during the fieldwork.

\subsection{Complex Legal System: Changing Legal and Economic Variables}

Given the isolation of the oasis and the concentration of settlers in fortified clusters near their lands, there is no space for extension inside the oasis, which isan issue that adds to the "morcelement" the oasis is facing. The legal status of the land is much more complex by inheritance issues. As a strategy against the restricted land size, farmers have tried to purchase abandoned land, but they have been faced with issues of heritage. According to Islamic rules, all children can have a share in the plot; thus, one can find a land of less than a hectare with many inheritors, some of whom are migrants. In such context, water discourses fail to take into account complex legal issues related to inheritance and land ownership. For instance, Islamic rules

17 Irrigate with potable water as it is cheaper in price per cubic meter is Dh 0.60 to Dh 0.66 . encourage people to stay together in unity and preserve the heritage, but in the case of the oasis most inheritance are small plots of less than 1 hectare which results in loosing interest and giving up the land since they have a small share. Concerning the economic variable, in the past, farmers had strong bounds with the land and water as there was a high level of dependency on the agricultural returns, but today farmers have other occupations (Fig. 17). Earlier farmers relied solely on the return from the agricultural plots but today farming is becoming a second priority or "hobby" farming [9], a situation that raises questions about the sustainability and the future investment allocated to both agriculture and irrigation.

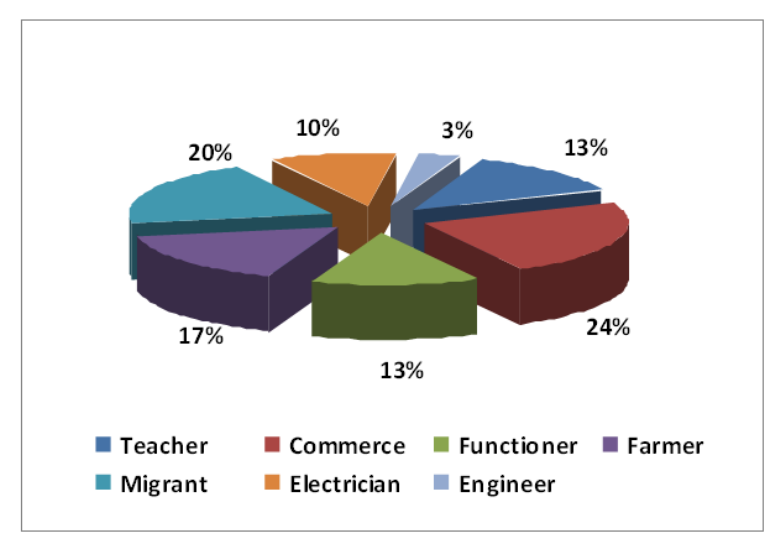

H, El Jamali, fieldwork and interviews, (2011)

Figure 17: Occupations of Farmers inside the Community

\subsection{Production and Profitability}

Most agricultural products produced in the plots are directed toward household consumption in the first place rather than to investment. Most products, mostly dates and olives ranging from $\mathrm{Kg} 500$ and $\mathrm{Kg} 2000$ for dates, are sold on the local market of the oasis. The collective management is shaped by moderate profitability, according to fieldwork interviews, a farmer's profitability ranges from zero profitability to Dh 20,000 per year, for farmers with the bigger share of water resources in good climate and high level of water flow. For community management, it is difficult to compete in terms of agricultural products with products coming from other cities in Morocco, mostly from the Gharb area, which is a large-scale scheme irrigation that has been strongly supported by the government.

The community welfare depends on groundwater; its water availability itself is dependent on weather conditions. The charges of the pumping station are supported by the rented water rights, but solely relying on remittances. Twothirds of the land in the cluster are abandoned because of increased migration and complex legal system affected by inheritance. Labor workers in the oasis have decreased in number. As the migrant does not contribute to the fees and the charges of the land, and the landowner takes half of the production, laborers are discouraged to work the land. As remittances have brought about an increase in the price of both the ownership of land and the rented water rights, 
many migrants leave behind them a complicated legal situation of land inheritance. Even if thecommunity is given high autonomy, it lacks financial and technical assistance to face such sharp market competition and environmental conditions. Small external aid, given by some international organizations mainly in training and in workshops, benefits only a few privileged members. As a result, any imbalance in any of the conditions and factors under collective management becomes an invitation for free-riders. A number of factors have shaped traditional management inside the oasis. Environmental, social, cultural, economic and legal variables all affected community management inside the oasis. Given the difficulties and the inequalities in the collective management, is it better for farmers to stay with the community or to invest outside? Is any free-riding a threat to the community management? These questions are elaborated in the next sections.

\subsection{Oasis Transformation: Al Arja Extension}

\subsubsection{Land and water Ownership}

The difficulties faced by community management have resulted in a recent extension outside the fortified oasis. Recent extension emerged in the Al Arja area, north of the oasis, using wells to drain water from water tables. The first investment started during the 1990s, but in the year 2000, many individuals started investing in the area. The availability of both water and good soil encouraged a certain group from the community management cluster and some other individuals to free-ride outside the community management. The number of owners is 59 (of whom 20 farmers are from the cluster of Lüdāghìr) using 60 wells. The area covers ha 4000 used by three different clusters: Larmour, the original owners, At Slimane cluster, and $L \bar{u} d \bar{a} g h \bar{i} r{ }^{18}$ The right to extract water is linked to the legal status of the land; this situation has resulted in an entanglement between modern and traditional laws. Important famers own between 9-11 hectares (see Table 3) while only two farmers own between ha 12 to more than ha 30. The fieldwork revealed that small investments of a few hectares where made during the 1990s; however, since 2000, farmers have been investing in large areas.

Table 3: Farmers' Land Size and Date of Investment

\begin{tabular}{lll}
\hline $\begin{array}{l}\text { Size of the land } \\
\text { (hectare) }\end{array}$ & Farmers & $\begin{array}{l}\text { Starting Date of } \\
\text { Investment }\end{array}$ \\
\hline $5-7$ & 1 & $1994-95$ \\
$7-9$ & 1 & $98-2000$ \\
$9-11$ & 3 & 2005 \\
$12-14$ & 1 & 2006 \\
$>30$ & 1 & 2008 \\
\hline
\end{tabular}

H, El Jamali, fieldwork and interviews, (2011); N=7

\footnotetext{
${ }^{18}$ Land in the area was given by Larmour to the cluster of Lūdāghīras a reward to people of the cluster for their help to the settler of the area.
}

In the case of Al Arja, farmers use water tables (aquifer), in which the volume of water is generally lower than the refill. The latter can be explained by the duration farmers spend to extract their water. Some farmers use their wells $24 \mathrm{~h}$ a day; others use it from oneto nine hours per day. [Professor Al Otmani, personal communication, March $5^{\text {th }}$, 2011]. Farmers own from two to threemotor-pumps (vertical axe) taming for water according to their position vis-à-vis the river of Al Arja, located north. Farmers near the river can just tame 10 meters for water, but people far from it can reach 45 meters. Water flow differs according to the number of wells and the location near the river, for instance, one pumping well can give 100-150 L/min. For the quality of the soil, the new extension has sandy soil, which is favourable for growing vegetables. Water itself is less salty than the one inside the oasis, which is a good environment for agriculture. However, due to the geological position, the area is threatened by desertification.

\subsubsection{Technology and Agricultural Products}

The extension is marked by the introduction of new technologies namely drip-irrigation, sprinklers, and reservoirs to store water totalling fivetons of water. While some farmers are still using the flooding technique in some specific spots, the majority has adopted new technologies. Among the farmers being interviewed, only two have permission for pumping and owning wells, and they have conducted a study before investing; the majority of farmers have neither permission nor a technical study of the area.The average number of wells a farmer can own is two wells; the majority of famers have three wells set in different locations in the plot. Adding to this, the farmers have a settlement building for the labourer living permanently on the land. The owner can be a migrant abroad or in Morocco.

The new techniques in use help in the conservation of the resource. According to Mr. Badi, Agriculture Centre, "palm trees inside the oasis are given around $100 \mathrm{~L} / \mathrm{d}$ what we refer to as 'irrigation à pied'whereas outside palm trees are given $2 \mathrm{~L} / \mathrm{d}$ which is sufficient for the tree" [personal communication, February $\left.15^{\text {th }}, 2011\right]$. The agricultural pattern is designated around palm trees; they are planted first as much as they require an average of five years or more to yield production. All others including trees, olives, almond, vegetables, fruits, additionally to animal husbandry comes second to palm trees. ${ }^{19}$ Different cropping strategies are adopted. It was observed that a farmer has around 400 palm trees as a single plantation. Others adopt different products mainly palm trees, vegetables, and fruits. While waiting for the return from the palm trees, farmers invest and intensify their production of vegetable to help in the expenses of the investment. Other farmers adopted other agricultural products, given good climate and soil conditions, like lettuce, cucumber, peanuts, and pistachios.

\footnotetext{
${ }^{19}$ To fortify his land the farmer uses cane, trees like olives and pomegranate, cable fence.
} 


\subsubsection{Investment and Profitability}

The extension is shaped by the capacity of the farmer to invest. Some adopt family arrangements whereby two brothers share one investment. According to the fieldwork interviews, the investment in the area requires a long-term commitment, where the cost of investment ranges from $\mathrm{Dh}$ $5,000,000$ to $\mathrm{Dh} 6,000,000$. For instance, to install and dig the well, a farmer needs between $\mathrm{Dh} 5,000$ for lands near the river and $\mathrm{Dh} 10,000^{20}$ for land farther away. The majority of the crops are palm trees, which need from fiveto tenyears to yield the benefits. Therefore, the profitability is dependent upon water availability, and capacity to invest. Most farmers need to wait for at least 5 to 10 years for some return. However, given the high rainfall variability and extensive years of drought, profitability cannot be assured. The profitability is higher than that under community management, given the space and the production, as it ranges from $\mathrm{Dh} 60,000$ to $\mathrm{Dh}$ 500,000 per year. Some unique varieties of dates like $A z i z a^{21}$ can be profitable, as it is of unique quality, known only in the region.

\subsubsection{Environmental and External Constraints}

New investments have been faced with major challenges. Farmers are challenged with commercialization issues, as they face storage and conservation problems. The Al Arja area is located far from the oasis, which needs storage and conservation places, thus increasing the charges for transport and commercialization. Moreover, farmers cannot benefit from agrarian reforms or the "Green reforms" because of the nature of the legal system of properties. Property should belong to the owners, but, in this case, the property is under the legal framework of $L \bar{u} d \bar{a} g h \bar{i} r$ cluster [Kalifi, personal communication, February $\left.24^{\text {th }}, 2011\right]$. The investment is recent and requires a long-term commitment. The aquifer in the area is subject to variability and rainfall, thus affecting the level of infiltration in the aquifer. The investment is strongly impacted by the capacity of farmers to invest while strong factors, like the quality of soil and desertification, bear upon the infiltration of the aquifer [26]. In addition, the lack of control in the use of wells and the lack of previous studies affect the sustainability of the investments. A clear absence of the state intervention and policies in such an arid and crucial oasis encourages unorganized people to free-ride.

Past theories and discourses about water management ignored demographic and economic variables. For instance, exodus has been ignored by the three authors (Wade, Ostom, Platteau), but strongly emphasized by Agrawal. The role of migration has been crucial, for remittances from migrants which have been used to improve the economic situation. In Figuig, so much sothat by $1982,43 \%$ of the male population had had at least immigration

\footnotetext{
${ }^{20}$ Thought the price for wells is cheap but it requires constant control because of the desertification aspect.

${ }^{21}$ The price of Aziza can reach Dh 100 per $\mathrm{kg}$, which is the most expensive date in the region.
}

experience[8].Many returnees have been purchasing more land and water rights. Another group of returnees have introduced technologies and enlarged land areas to increase production. In terms of the plots: remittances have been used to maintain the plot inside the oasis, to buy more water rights, to introduce new techniques(plastic canalization)and cropping patterns, and to fortify the parcel that used to be an open access to everyone [27]. Migration has an effect on the oasis and how people perceive the space, cropping patterns, and the use of technology. Some farmers invest to avoid the disappearance of a familial heritage, while others try to increase the production. Under such evolving circumstances, past policies mainly defining IWRM approach is difficult within such permanent changing oasis society. Water has been regarded as an economic good in the oasis of Figuig, however, the latter is more than an economic good it is a social and cultural asset, the political and social assets has restricted the market intervention [28].In relation with IWRM approach, water property rights, pricing, and the flow of water remained constant even if the oasis has witnessed major changes and transformations. The Jma' 'ah needs to accommodate the $k h a r \bar{u} b \bar{a} h$ unit given the variability in water flow. Social, political, cultural, legal, and environmental uncertainties together have strongly affected the supply and demand model promoted by water management discourses. Rainfall is strongly correlated with infiltration, thus, good rainy seasons imply good infiltration and potential for water tables and vice versa.

In a society of constant adjustment, there is a need to adapt institutions to accommodate change. Ostrom stated that in establishing institutions to provide and contribute to irrigation, there exists no "one best way" [29]. There is a need to take into account environmental, social, and political changing dynamics. For instance, in the Oasis of Figuig, both community and lately individual initiatives managed to survive, adopt, and adjust to change. Notwithstanding the shortcomings of such initiatives, inequalities and free-riding both managed to adapt to the changing reality of the oasis. What discourses seemed to fail to recognize is the existence of what Ostrom called "multiple action arenas" [25, p. 228] shaping water management. In such dynamic and changing context, water management paradigms show shortcomings to take into account the complex local arrangements witnessed in the field.

\subsubsection{Evolution Versus Devolution of the Oasis}

Both water and land are confronted with environmental constraints. The use of water is disputed between domestic and agricultural usage. Water availability decreases in summer given the high number of migrants. Land is also shaped by dispersed small size and further affected by inheritance complications. Concerning water availability, one wonders if the oasis is facing a water crisis. According to a recent report from MoulouyaBasin Agency, the oasis has potential resources as the renewable resources are about 13 
Million cubic meters of groundwater at the level of the oasis. Water flow in water tables is 4.4 Million cubic meters and 11.5 Million cubic meters in deep aquifer [Table 4].

Table 4: Renewable Resources in the Oasis of Figuig (in Million Cubic Meters) [15]

\begin{tabular}{|c|c|c|c|c|}
\hline Terms & $\begin{array}{l}\text { Figuig } \\
\text { Groundwater } \\
\text { Table }\end{array}$ & $\begin{array}{l}\text { Tisserfine- } A l \\
\text { Arja } \\
\text { Groundwater } \\
\text { Table }\end{array}$ & $\begin{array}{l}\text { Deep } \\
\text { Aquifer }\end{array}$ & Total \\
\hline $\begin{array}{l}\text { Direct } \\
\text { infiltration of } \\
\text { effective } \\
\text { rainfall }\end{array}$ & 0.33 & 1.34 & 11.53 & 13.2 \\
\hline $\begin{array}{l}\text { Irrigation } \\
\text { return }\end{array}$ & 1.8 & 0.25 & - & 2.05 \\
\hline $\begin{array}{l}\text { External } \\
\text { inputs } \\
\text { drainage }\end{array}$ & 2.31 & 2.04 & - & 4.35 \\
\hline
\end{tabular}

The table shows a moderate "recharge" given the aridity of the oasis. The oasis has a great potential of deep aquifer, but the latter needs to undergo further study. The oasis is threatened by the widespread recent trend of extensive pumping over the oasis; they number 108 stations of which $51 \%$ are located in $L \bar{u} d \bar{a} g h \bar{t} r$ cluster. However, the levels of water tables and the flow of resource spring do not seemto be affected by the introduction of private individual wells. From the evolution witnessed in the oasis in the past 50 years, a great transformation has taken place in the oasis space. First, the agricultural space and its irrigation have increased as arable land and palm tree cultivationhasincreased. As a result, concerns regarding the death of the oasis can be misleading. Second, remittances play a crucial role in reviving old plots. Returnees have embarked on purchasing new water rights to increase their production, and they use modern tools. Remittances come not only from abroad but also from internal migrants who make important investments. However, in the last 10 years, remittances have decreased from $\mathrm{Dh} 50$ and Dh 55 Million to Dh 12 Million in 1992 and 2002, respectively[17]. Can remittances sustain the oasis in longterm? How would a decrease in remittances bear upon the oasis? Third, the new transformations have occurred, outside the oasis, where private and community individuals invest outside the oasis. Consequently, the question on the death of the oasis seems moot as the oasis is witnessing constant change and evolution.

\section{Conclusion: Conditions of the Common Pool: Community versus Private}

Water management has until now been considered common good, under community management, and within a set system of social organization. Today, it has shifted to an individualistic management. Water theories failed to recognize that both community and private management can co-exist. The community system has been altered and changed by the following: low profitability compared to individual investment, as it is mostly targeted toward household self-consumption. The new individual initiatives have created new dynamics in the Al Arja area. Based on nomad use in the past, it now profits from investments that have backed up agriculture production increase in the oasis, have created new job opportunities, and have developed a new zone for investments, which is endowed with electricity and roads linking it to the oasis. However, recent evolution and extensions in the oasis is strongly correlated with climate conditions. The introduction of new technologies and long-term investments are all replenishing by the aquifer level and its recharge. Today, the Al Arja area is witnessing a race over purchasing more lands, extending toward the oasis, and taming most water, resulting in overexploitation of a scarce resource. Both time-framework and risk factors should be taken into account to evaluate such initiatives.

There is no clear, direct impact of private initiatives on the community inside but pumping from the same water tables might have a strong influence on the Oasis sources [15].Therefore, there is need for strong public intervention and institutions to control free-riding in an open space, issuing pumping permits, and organizing individual investment with an organized legal framework. Given the problems facing agriculture, new voices, including farmers', have been fostering tourism ${ }^{22}$ as an alternative for agriculture in the oasis. However, there is a need to take into account the instability of agriculture and the shortage of water for both tourism and agriculture. Tourism will become a rival of agriculture, which is already suffering from aridity and drought. Recently, a mobilization has taken place for surface water allocation through the Sfaisaf Damof which the constructions started in 2008. The Sfaisaf Dam will provide water to the community cluster byreviving the khettara system and setting individual vanes in Al Arja sector. The dam will provide 4 Million cubic meters of water and, more importantly, it will help in reviving and enriching the aquifer and the water table in the oasis. However, the solution adopted by the state is still limited to physical answers to face the scarcity threatening the oasis, and the new dam is a witness to that. New interests should focus on examining social, cultural, and economic factors shaping the oasis, and on strengthening the oasis institutions. The oasis has witnessed an evolution and is undergoing new transformation as individuals invest in new extension outside the oasis with high capacity in venture capital. The future of such investments is still unsure. At the same time, community management is facing sharp inequalities and challenges as well as low profitability, leading to a need for public policy to preserve the common resource and to provide equal water sharing. What is even worse is the absence of a sanitation system inside the oasis that is threatening the quality of water. As a result, the issues of preserving the oasis, its community

\footnotetext{
${ }^{22}$ The Oasis is promoted as anational heritage in the country.
} 
system and, more importantly, correcting the inequalities and preserving a scarce resource are all factors that should be addressed by policy makers. The oasis is shifting from one model to the other in order to sustain its system and to ensure its survival. Past water management discourses have showed their disenchantment; as there is no one model for effective water management. There is a need to examine different strategies, logics, and local realities in different and overlapping contexts and settings.

\section{Glossary}

Al-rama:a term referring topeople who are not descended from the prophet family.

Al-kade: official entitlement of water rights.

Sarayfi: a person assigned by the community to allocate and manage water.

At-Lasl: people owning private water rights.

Charia:Islamic Law.

Chargui: strong hot winds in summer.

Dh: Moroccan Dirhams (1 $\mathrm{Dh}$ is equivalent to euro 0.0885).

Foggara: an Iranian technique known by qanat using gravity for irrigation purposes.

Haratine: an Arabic word for African groups settling in the Oasis of Figuig.

Ifli; (Iflan plural): a technique using gravity to distribute water from the hill to the plots through canals. It is known as foggara system.

Gammoun: the smallest part in an agriculture property in the oasis. Gammoun is equivalent to 10 meters * 2 meters.

Iqū $\bar{a} s:$ a type of canals used to distribute water.

$J m \bar{a}$ 'ah: community group managing the cluster.

Janān: an agriculture plot or land.

Kharūbāh: 45 minutes of water allocation.

Qaşr (qusūr plural): cluster.

Sahrij: a small basin used for irrigation in the parcel.

Saguia: canal.

Shurfa: descended from the prophet.

Tanatawte: a day added to the 15-day water cycle whose money is used for collective projects within the community.

Rabta or tasrount: flooding techniques of irrigation.

Twiza: a day devoted by the community to collective work like harvesting or maintaining irrigation canals.

Urf: customary rule.

Zenetes, Senhaja: Berber tribes settled in the Oasis

\section{References}

[1] R. Meinzen-Dick, V.K. Raju, A. Gulati, What Affects Organization and Collective Action for Managing Resources? Evidence from Canal Irrigation Systems in India, WorldDevelopment. 30 (4) (2000) 649-650.

[2] D. Moss, The Symbolic Making of a Common Property Resource: History, Ecology and Locality in a Tank-irrigated Landscape in South India, Development and Change.28 (1997) 467-504.
[3] A. Agrawal, C.C. Gibson, Enchantment and Disenchantment: The Role of Community in Natural Resource Conservation, World Development. 27 (4) (1999) 629-649.

[4] E. Ostrom, Governing the Commons: The Evolution of Institutions for Collective Action, CambridgeUniversity Press, 1990.

[5] R. Wade, The Management of Common Property Resources: Collective Action as an Alternative to Privatisation or State Regulation, Cambridge Journal of Economics. 11 (1987) 95106.

[6] H. R. Wagner, The Theory of Games and the Problem of International Cooperation, The American Political Science Review. 77 (2) (1983) 330-346.

[7] A. Agrawal, Common Property Institutions and Sustainable Governance of Resources, World Development. 29 (10) (2001) 1649-1672.

[8] A. Bencherifa, H. Popp, L'oasis de Figuig persistance et changement, Rabat: Université Mohammed V, 1992.

[9] A. Ouassou, T, Ameziane, A, Ziyad, M. Belghiti, Chapter 19: Application of the Drought Management Guidelines in Morocco, Options Méditerranéennes, Series B. 58 (n. d) 343-372.

[10] A. Jilali, Caractérisation hydrogéologique de la nappe de Figuig- Maroc, Master's Thesis, Faculté des Sciences Département de Géologie, Unité d'hydrogéologie et Géologie de l'Environnement. Université de Liège, (2009) 22.

[11] Monographie 2010, Municipality of Figuig.

[12] A, Darti, Atawasour al filahi rala hawamich wahat figuig: mintakat al arja- tisirfine, (Extensions Outside the Oasis of Figuig: Al Arja Area), Master's Thesis, Faculty of Human Sciences, University of Mohamed I, Oujda, Morocco, (2000) 6-7.

[13] A. Meziane, "Figuig: Mousahama fi dirasat Al mojtama' alwahi almaghribi khilal alqarn attasi' 'achar, 1854-1903," (Figuig: A Contribution in the Study of an Oasis Society), Rabat: Fajr Asaada. (1988) 259-264.

[14] A. Hakkou, \& M. Bouakka, Programme de sauvetage de la palmeraie de Figuig et encouragement des coopératives agricoles, Département de Biologie-Laboratoire de Biochimie, Faculté des Sciences, Université Mohamed I, Oujda, Maroc, 2000.

[15] Agence du Bassin Hydraulique de la Moulouya-Oujda, Inventaires des Prélèvements d'Eau Souterraine à Partir des Nappes de la Plaine de Figuig et Elaboration des Cartes Hydrogéologiques de Gestion des Nappes, 2006.

[16] A. Marzouk, "Al majal walmojtama' fil wahat Al Maghribia," (Space and Society in the Oasis of Figuig), Master's Thesis, Faculty of Human Sciences, University of Mohamed V, Rabat, 1995.

[17] A. El Harradji, Les ressources et le développement durable de L'oasis de Figuig entre la gestion des crises et la crise de la gestion, L'Environnement oasien face aux mutations économiques et sociales: le cas de Figuig, Colloque international organisé par L'IRCAM a Figuig, les 24-25 avril 2006. 
[18] Bulletin Officiel 1975, Nº 3292

[19] T. Boutayed, Espace et société agro-pastorale en mutation dans le Maroc Oriental Steppique, Royaume du Maroc-Fès : Faculté des Lettres, Université de Fès, 2003.

[20] S. Siebert, J. Burke, M. Faures, J. K. Frenken, J. Hoogeveen, P. Doll, \& F. T. Portmann, Groundwater use for irrigation - a global inventory, Hydrology and Earth System Sciences. 14 (2010) 1863-1880.

[21] G. Green, D. Sunding, D. Zilberman, \& D. Parker, Explaining Irrigation Technology Choices: A Microparameter Approach, American Journal of Agricultural Economics. 78 (4) (1996) 1064-1072.

[22] R. M. Doukkali, Water Institutional Reforms in Morocco, Water Policy Journal. 7 (2005) 71-88.

[23] B. Lecestre-Rollier, La gestion de l'eau: une question d'identité le cas des vallées du Haut Atlas marocain, Actes du Séminaire PCSI, Montpellier, France, 2004.

[24] T. Madani, Le Partage de l'Eau dans l'Oasis de Figuig (Maroc Oriental) : Approche historique et archéologique, Nouvelle série. 36 (2006) (2) 61-81.
[25] E. Ostrom, R. Gardner, \& J. Walker, Rules, Games, and Common-Pool Resources. US: The University of Michigan Press, 1994.

[26] R. Jaubert, M. Al-Dbiyat, \& F. Debaine, Transformation des Régions Cultivées: Différenciation des Exploitations et Extension de l'Irrigation, Les marges arides du Croissant fertile, TMO 43, Maison de l'Orient, Lyon, 2006.

[27] S. Mizbar, Le poids de l'Agriculture dans le développement des provinces d'Errachidia et de Figuig au Maroc, Master's Thesis, Institut National Agronomique Paris- Grignon, Université de Nanterre, 1999.

[28] G. Meszoely, Water Resources Management in a SaharanOasis, Doctoral dissertation. Law, Policy and Society Program, Northeastern University, Boston: Massachusetts, 2006.

[29] E. Ostrom, Crafting Institutions for Self-Governing Irrigation Systems. California: Institute for Contemporary Studies, 1992. 